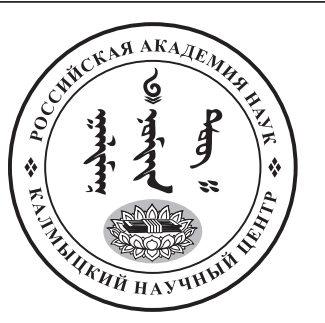

Published in the Russian Federation

Oriental Studies (Previous Name: Bulletin of the Kalmyk Institute

for Humanities of the Russian Academy of Sciences)

Has been issued as a journal since 2008

ISSN: 2619-0990; E-ISSN: 2619-1008

Vol. 14, Is. 3, pp. 595-605, 2021

Journal homepage: https://kigiran.elpub.ru

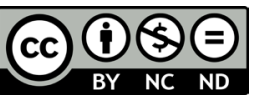

УДК / UDC 94(09)(=18/=03)

DOI: $10.22162 / 2619-0990-2021-55-3-595-605$

\title{
Лексико-семантический анализ топонимии чувашского села Большое Алдаркино Борского района Самарской области и его окрестностей
}

\author{
Николай Валерьевич Беленов 1 \\ ${ }^{1}$ Самарский государственный социально-педагогический университет (д. 65/67, ул. М. Горького, \\ 443099 Самара, Российская Федерация) \\ кандидат педагогических наук, доцент
} (iD)0000-0002-4415-5966. E-mail: belenov82@gmail.com

(C) КалмНЦ РАН, 2021

(C) Беленов Н. В., 2021

\begin{abstract}
Аннотация. Целью настоящей статьи является введение в научный оборот и анализ географической номенклатуры села Большое Алдаркино Борского района Самарской области, основанного выходцами из верховых чувашей в 1767 г. Материалами для данной работы послужили сведения по топонимии села Большое Алдаркино и его окрестностей, полученные автором статьи в течение полевого сезона 2018 г. от местных жителей и краеведов. Для сравнительно-сопоставительного анализа исследуемых топонимных единиц в работе привлекаются соответствующие материалы автора, собранные в других чувашских сёлах Самарского Поволжья на протяжении 2015-2019 гг., прежде всего - в Борском, Похвистневском и Исаклинском районах Самарской области. В результате исследования были выявлены основные элементы географической топонимной лексики большеалдаркинского говора чувашского языка, их формы бытования и семантика. Среди них можно выделить такие термины, как вар 'овраг', ошкень 'улица', структура, формы бытования и значения которых в данном говоре отличают его от чувашских говоров соседних сёл. Большинство представленных в статье названий этимологизируется из чувашского и русского языка, ряд топонимов в настоящее время деэтимологизирован, однако оснований относить их к какому-либо другому языку не имеется. Субстратный слой в исследуемом топонимическом пространстве отсутствует. В некоторых географических названиях прослеживаются черты верхового диалекта чувашского языка - Oдар, Bырас ouкень, Тихон ошкень. Несколько географических названий Большого Алдаркино и его окрестностей имеют убедительные лексические и семантические параллели в топонимических пространствах других чувашских сёл региона, а также иных территорий расселения носителей чувашского языка.
\end{abstract}

Ключевые слова: топонимика, географическая лексика, чуваши, чувашский язык, лексико-семантический анализ, этимология, Самарское Поволжье 
Для цитирования: Беленов Н. В. Лексико-семантический анализ топонимии чувашского села Большое Алдаркино Борского района Самарской области и его окрестностей // Oriental Studies. 2021. T. 14. № 3. C. 595-605. DOI: 10.22162/2619-0990-2021-55-3-595-605

\title{
Lexical and Semantic Analysis of the Toponymy of the Chuvash Village of Bolshoe Aldarkino, Borskii District of the Samara Region
}

\author{
Nikolay V. Belenov ${ }^{1}$ \\ ${ }^{1}$ Samara State University of Social Sciences and Education (65/67, M. Gorky St., 443099 Samara, \\ Russian Federation) \\ Cand. of Pedagogical Sc., Associate Professor \\ iD 0000-0002-4415-5966.. E-mail: belenov82@gmail.com \\ (C) KalmSC RAS, 2021 \\ (C) Belenov N. V., 2021
}

\begin{abstract}
The article deals with the inventory of toponyms of the village of Bolshoe Aldarkino, Borskii district, Samara region, introduced and analyzed for the first time by the present author. The village was founded by the descendants of Virjal Chuvash in 1767. The research database has been formed by the evidence on the toponymics of the village and its surrounding area collected by the author from locals and local historians during his field trip in 2018. Also, for a comparative analysis of the toponyms under study, he has made use of the relevant material collected by him in other Chuvash villages of the Samara Volga region in the period between 2015 and 2019; these are first of all the villages in Borskii, Pokhvistnevskii, and Isaklinskii districts. As a result, it was possible to identify the principal elements of the toponymic items of the Chuvash idiolect of Bolshoe Aldarkino, their particular forms and semantics. To illustrate, such terms as var (ravine) or oshken'(street) have peculiarities in their structure, forms, and semantics, which make them distinctly characteristic of this particular Chuvash dialect in contrast to those spoken in the neighboring Chuvash villages. Most of the names presented in the article are etymologized from the Chuvash and Russian languages, a number of toponyms are currently de-etymologized, but there are no grounds to refer them to any other language. There is no substrate layer in the toponymic space under study. Some geographical names display the features of the Virjal dialect of the Chuvash language, including Odar, Vyras Oshken, Tikhon Oshken, etc. A few geographical items of the toponymic space of Bolshoe Aldarkino have convincing lexical and semantic parallels in the toponymic spaces of other Chuvash villages in the region, as well as of other settlements of Chuvash speakers.

Keywords: toponymy, geographical lexicon, Chuvash, Chuvash language, lexical and semantic analysis, etymology, Samara Volga region

For citation: Belenov N. V. Lexical and Semantic Analysis of the Toponymy of the Chuvash Village of Bolshoe Aldarkino, Borskii District of the Samara Region. Oriental Studies. 2021. Vol. 14 (3): 595-605. (In Russ.). DOI: 10.22162/2619-0990-2021-55-3-595-605
\end{abstract}

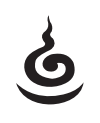

\section{Введение}

Исследование топонимии того или иного населённого пункта представляет интерес сразу с нескольких сторон: в топонимии консервируется архаичная лексика, вышедшая из употребления в соответствующем говоре; в ней отражаются этноязыковые, культурные, хозяйственно-бытовые и религиозные особенности жителей соответствующего села; субстратный топонимический слой, если он сохранился, может дать представление о том, носители каких языков населяли данные территории ранее. 
Целью настоящей статьи является введение в научный оборот, лексико-семантический, этимологический и сравнительно-сопоставительный анализ топонимии села Большое Алдаркино Борского района Самарской области, располагающегося на территории реликтового островного массива соснового леса в степях Заволжья, известного под названием Бузулукский бор.

История села относительно полно документирована. Согласно материалам Е. А. Ягафовой, оно было основано в 1767 г. выходцами из верховых чувашей, что нашло отражение в местном языке и культуре [Ягафова 1998: 82].

Вместе с аверкинскими чувашами, проживающими в Похвистневском районе Самарской области, жители Большого Алдаркино и ряда других чувашских сёл Борского района составляют редкий, за пределами Чувашии, анклав компактного проживания носителей верхового диалекта чувашского языка.

В 1865 г. алдаркинскими чувашами, совместно с чувашскими переселенцами из других мест, было основано ещё одно село, которое назвали Малое Алдаркино, а само Алдаркино, соответственно, получило эпитет Большое.

В среде жителей Большого Алдаркино имеет распространение версия, что история возникновения их села тесно связана с историей чувашского села Алдаркино-Подколки (ныне - Алдаркино Бузулукского р-на Оренбургской области), точная дата основания которого неизвестна, но, по материалам местных краеведов, приходится на период 1750-1792 гг. [Рукопись 1998: 5].

В то же время ряд сведений указывает на то, что чуваши Большого Алдаркино находятся в ближайшем родстве с жителями чувашского села Ново-Геранькино Борского района Самарской области [ПМА 2018: инф. 1; ПМА 2018: инф. 2; ПМА 2019: инф. 3; ПМА 2019: инф. 4]. Так, до середины XIX в. село Большое Алдаркино именовалось Алдаркино-Геранькино. Кроме того, чувашские говоры указанных сёл характеризуются практически идентичным кластером географической лексики, нередки общие элементы географической номенклатуры в топонимических пространствах данных сёл, причём параллели отмечаются как лексические, так и семантические [ПМА 2018: инф. 1; ПМА 2018: инф. 2].

\section{Историография}

Одним из первых исследований, посвящённых специальному изучению чувашских географических названий, следует признать «Корневой чувашско-русский словарь» Н. И. Золотницкого и его же статью «Лингвистическая заметка о названиях Булгар, Биляр и Моркваши» [Насилов, Бурыкин 2017: 147].

Отдельные сведения об этимологии чувашских топонимов приводятся в работах Н. И. Ашмарина [Ашмарин 1902; Ашмарин 1921], среди которых следует особо отметить его словарь чувашского языка, содержащий более девяти тысяч статей, посвящённых именам собственным [Ашмарин 1928-1950], а также Г. И. Комиссарова, Н. В. Никольского [Комиссаров 1911; Никольский 1911]. В этом ряду также необходимо отметить оставшийся, к сожалению, неизданным труд В. К. Магницкого «Опыт историко-географического словаря Казанской губернии», автор которого известен работами по чувашской антропонимии [Магницкий 1905].

Далее следует отметить недавно переизданный труд В. А. Нестерова (1980) [Нестеров 2017], работу А. А. Сосаевой [Сосаева 1997].

Среди научных квалификационных работ, близких по тематике к теме нашего исследования, выделяется кандидатская диссертация А. С. Ивановой, посвящённая чувашской гидронимии [Иванова 2005].

Значительную долю внимания чувашской топонимии в своих работах по топонимике Среднего Поволжья уделяет Г. Е. Корнилов [Корнилов 2005].

Среди новейших исследований на данную тему следует отметить труды Ю. Н. Исаева [Исаев 2018; Исаев, Исаев 2018].

Топонимия чувашей Самарского Поволжья до настоящего времени не составляла предмет специального исследования. Тем не менее отдельные сведения об этимологии чувашских топонимов региона можно найти в работах по истории и этнографии чувашей Самарской Луки, Заволжья [Симаков 2008; Димитриев 1993; Ягафова 1998; Юмарт 2003], а также в общих исследованиях топонимии Самарской области [Барашков, Дубман, Смирнов 1996]. 


\section{Материалы и методы}

Материалы исследования получены нами в результате сбора географической номенклатуры села Большое Алдаркино Борского района Самарской области и его окрестностей в течение полевого сезона 2018 г. Значительную часть сведений по топонимии Большого Алдаркино мы почерпнули из материалов местного краеведа, ветерана Великой Отечественной войны Дмитрия Ивановича Ерицева [ЛА 2018]. В период 2015-2019 гг. аналогичные исследования были проведены автором в ряде других чувашских сёл Борского, Исаклинского и Похвистневского районов, материалы которых легли в основу сравнительного анализа исследуемой топонимии.

Методы исследования обусловлены целью и задачами исследования, в контексте решения которых мы обратились к методикам изучения топонимии ведущих отечественных специалистов в данной области: А. А. Бурыкина, А. К. Матвеева, В. А. Никонова, Б. А. Серебренникова, В. И. Супруна [Бурыкин 2014; Матвеев 2006; Никонов 1965; Серебренников 1959; Мадиева, Супрун 2015].

\section{Анализ топонимии села Большое Ал- даркино}

Рассмотрим последовательно географические названия села Большое Алдаркино и его окрестностей.

Алдаркино. Титульный ойконим исследуемого топонимического пространства. Судя по структуре названия, а также ввиду близких ойконимических параллелей (Геранькино, Сидоркино) следует указать на отантропонимный характер его происхождения. Чувашское языческое имя Алдар фиксируется В. К. Магницким в его специальной работе по чувашским традиционным именам [Магницкий 1905: 25]. Данное имя восходит к лексеме алтӑр со значением 'большой деревянный ковш'.

В селе параллельно бытует ещё одно его название - Турьял. В основе последнего ойконима лежат две чувашские лексемы: тури 'верхний' + ял 'деревня, село' Происходит он либо от названия главного оврага села - Тури вар, либо отражает тот факт, что Большое Алдаркино по отношению к Малому Алдаркино располагается выше по течению реки Cupмыл. Наконец, надо отметить, что тури, наряду с вирьял, является названием верховых чувашей. Однако маловероятно, что топоним восходит к данному этнониму, поскольку местные чуваши именуют себя исключительно вирьял, тогда как чувашей сёл Рысайкино, Стюхино и ряда других, расположенных по правому берегу реки Кинель, разговаривающих на низовом диалекте, называют хиртяк 'степняки’ [Канюкова 1965: 133].

Анат. Название южной (низинной) части улицы Тихон вар. В чувашском языке лексема aнат имеет значение 'низовье', 'нижняя часть чего-либо'; в некоторых диалектах имеет значение 'восточный'.

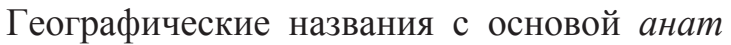
являются распространённым элементом чувашских топонимических пространств. Отметим лишь некоторые параллели из чувашской топонимии: Анаткас - урочище в Большом Чувашском лесу на Самарской Луке [Барашков, Дубман, Смирнов 1996: 14], Aнат nус - поле у села Елаур Сенгилеевского р-на Ульяновской области, Анат Чаткас — параллельное название села Чепкас-Никольское Шемуршинского р-на Республики Чувашия и т. д.

Bырас ошкень. Название одной из улиц села, располагающейся за оврагом Kuреметь. Согласно сведениям Д. И. Ерицева, название возникло вследствие того, что здесь поселились русские семьи, носители фамилий Осиповы, Суриковы, Скрипины; от чувашской лексемы вырӑс — 'русский'. Следует отдельно сказать о термине ошкень, бытующем в большеалдаркинском говоре в значении 'улица'. Обычно в чувашской топонимии в данном значении употребляются иные лексемы - урам и касcы. По нашему мнению, большеалдаркинский термин ошкень восходит к чувашской лексеме ушкӑн, среди широкого спектра значений которой присутствуют также 'часть селения', 'околоток’, ‘конец деревни’ [Ашмарин 1929, III: 354], в исследуемом говоре — с характерным для верховых чувашей гласным [о] вместо [y] в начальном слоге. Палатализация финального согласного, по всей видимости, явилась следствием выпадения чувашского аффикса принадлежности третьего лица [ё], что фиксируется Л. П. Сергеевым в ряде примеров из верховых говоров [Сергеев 2007: 86-87]. По-видимому, семантический переход в данном случае обусловлен тем, 
что ранее чувашские поселения характеризовались гнездовой застройкой, дома располагались группами; улиц, в современном понимании, в них не было. Затем, когда они появились, названия прежних околотков были перенесены на соответствующие улицы.

Индюха. Пруд в Большом Алдаркино, располагавшийся в нижнем течении реки Малды сирма, ныне не существующей. Согласно мнению наших информантов, в основе названия пруда лежит антропоним-прозвище [ПМА 2018: инф. 1]. Отметим также, что в чувашском антропонимиконе имеются созвучные лимнониму языческие имена (см., например: Идюха, Индей [Магницкий 1905: 43-44]), которые также могли послужить основанием для предполагаемого прозвища, от которого, в свою очередь, произошло название пруда.

Ирдек. Название одного из районов Большого Алдаркино. По объяснению Д. И. Ерицева, так называлась одна из улиц села по правому берегу реки Cupмыл, в основе названия лежит чувашская лексема upm 'миновать', 'проследовать мимо'. По его предположению, ещё до возникновения здесь улицы, по этому месту проходила обходная дорога мимо села [ЛА 2018: 2].

Карниловы кубы. Название урочища в окрестностях Скобелевского пруда. По воспоминаниям наших информантов, раньше там «варили дёготь, жгли древесный уголь» [ПМА 2018: инф. 1]. Карнилов - фамилия барина, организовавшего в Бузулукском бору данную деятельность. По-видимому,

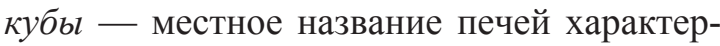
ной формы для перегонки дёгтя. Обмуровка котла-корчаги для производства дёгтя действительно часто имела кубическую форму.

Киреметь. Название одного из небольших оврагов, впадающих в Тури вар. По мнению Д. И. Ерицева, название дано по имени человека, труп которого был обнаружен в этом овраге [ЛА 2018: 2]. В большинстве топонимических пространств чувашских сёл урочища с такими названиями отмечают расположение мест языческих молений. При этом сам термин киреметь / кереметь, являющийся опосредованным заимствованием из арабского, в чувашском языке достаточно многозначен. Изначально, видимо, он означал могущественного духа, чаще всего — злого [Егоров 1964:
113], вследствие чего мог являться составляющим его имени собственного.

Н. И. Ашмарин приводит следующее толкование рассматриваемой лексемы: «Киремет есть место, где пребывает злой дух, например, дух какого-нибудь известного, некогда жившего на этом месте чувашина, представляющего собой героя» [Ашмарин 1934, VI: 230].

Известно несколько таких киреметей, названия некоторых из них, по мнению ряда учёных, восходят к именам политических и религиозных деятелей булгарского и ордынского периодов истории Поволжья, например, известная в прошлом у чувашей различных сёл киреметь Валем-хузя (Малем-хузя) [Ашмарин 1921].

В дальнейшем киреметями у чувашей и у некоторых финно-угорских народов Поволжья стали называться также площадки для ритуальных действий. В большеалдаркинском говоре, как и в ряде других чувашских говоров Самарского Заволжья, в данном значении термин киреметь был вытеснен лексемой чйк, что также нашло отражение в топонимии. Ранее у чувашей это были разные моления, совершаемые на различных площадках, расположение которых относительно села было строго регламентировано. В настоящее время у чувашей Большого Алдаркино и окрестных сёл подобное разделение отсутствует [ПМА 2018: инф. 2].

Представляется, что объяснение топонима Д. И. Ерицевым основано на том, что, согласно позднейшим религиозным воззрениям чувашей, киреметью также мог стать неупокоенный дух убитого либо умершего неестественной смертью человека.

Курмыли. Название одного из районов Большого Алдаркино, до середины XX в. в селе бытовали названия Верхний Курмыли и Нижний Курмыли. Термин курмыли имеет достаточно широкое распространение в Поволжье, встречаясь, в том числе, в названиях ряда населённых пунктов. Его происхождение остаётся неясным, однако надо отметить, что он часто встречается в мокшанских и эрзянских говорах, в которых имеется значительная доля урбонимных терминов с основой кур.

Максимовский пруд. Название пруда, располагающегося в верхней части села Большое Алдаркино. Являясь объектами 
рукотворными, пруды чаще всего получают своё название по имени (фамилии, прозвищу) человека, который либо сам его организовал, либо являлся инициатором сооружения. Реже пруды именуются по их позднейшему владельцу, в населённых пунктах бывает и так, что название пруду даётся по имени человека, живущего в непосредственной близости от него. В рассматриваемом случае мы имеем точную информацию о происхождении названия. Со слов информантов, пруд получил название ввиду того факта, что большинство домов в его окрестностях принадлежало жителям села с фамилией Максимовы [ПМА 2018: инф. 1].

Малды сирма. Название небольшой реки, ранее протекавшей через Большое Алдаркино, в настоящее время река не существует. Топоним относится к пространственно-ориентационным и отражает относительное расположение объекта: малти 'передняя' + сирма 'река' = 'передняя река' Названия подобного рода относительно часто встречаются в чувашской топонимии, сравните: названия населённых пунктов Малти Пасна, Малти Пукаш, Малти Терес̧, Малти Чипер уй, Малти Ииек и др., урочище Малти пусӑ, кереметь Малти Хурӑнсур киремечӗ, названия полей Малти-карта и Малти-ой.

В чувашской гидронимии подобные названия реже, но также встречаются: Maлmu-йу”ne — название реки — 'Передняя развилка', Малти сырма - название поля, луга на месте пересыхающей реки в Аликовском районе Чувашии, Малти пёве название пруда в Ибресинском районе Чувашии [Иванова 2005].

Согласно сведениям Д. И. Ерицева, река Малды сирма питалась от родников в лесу, которые в настоящее время исчезли. Вероятно, на месте данной реки в Большом Алдаркино в настоящее время располагается пруд Индюха.

Мукакино. Название части села до моста через реку Сирму. Со слов информантов, раньше там была мельница, муку мололи, со всей округи зерно свозили [ПМА 2018: инф. 1]. Если название не связано с фамильной основой, то можно предположить его происхождение от чувашского мукка (детское) — 'корова', 'собака', 'страшилище' [Ашмарин 1935, VIII: 258]; менее вероятно происхождение от русского слова мука.
Одар. Название урочища к востоку от Большого Алдаркино. Происхождение данного топонима информантам неизвестно. Можно предположить, что в его основе лежит чувашская лексема уmap 'пасека, пчельник' (в верховом диалекте - omap) [Федотов 1996, II: 294], 'местность, богатая растительностью и цветами для пчёл' [Егоров 1964: 278].

Подобные названия фиксируются в $\mathrm{Ca}-$ марском Поволжье и в топонимических пространствах мордовских сёл, где однозначно трактуются информантами как иноязычные и связываются с чувашами; ср.: Отарлей в окрестностях эрзя-мордовского села Старая Шентала Шенталинского р-на Самарской области, отар - неэтимологизируемая информантами основа + лей 'река'.

Д. В. Цыганкин также отмечает топонимы с основой отар на территории Республики Мордовия, где этимологизирует их от адаптированной в чувашском языке русской лексемы хутор [Цыганкин 2005: 256]. Это же значение для данной лексемы отмечает и Н. И. Ашмарин [Ашмарин 1929, III: 326].

Впрочем, для ряда надёжно фиксируемых топонимов формы Oдар / Omap в топонимических пространствах как чувашских, так и мордовских сёл, этимологию от слова хутор можно заведомо исключить. Интересно также отметить, что А. В. Дыбо считает, что русское слово хутор само является ранним заимствованием из булгарского языка [Дыбо 2013].

Пилюлька. Пруд, располагающийся в средней части села. Согласно объяснениям наших информантов, своё название объект получил за характерную форму, напоминающую таблетку [ПМА 2018: инф. 1]. Название позднего происхождения (80-90 гг. XX в.).

Сирма. Река, протекающая через Большое Алдаркино, правый приток реки Самары, в настоящее время сильно обмелела. Потамоним восходит к чувашской лексеме с̧ырма 'овраг', 'небольшая река'. Официальное название этой реки - Алдарка, фиксируемое на картах с середины XIX в. [Карта 1867], является русским и в большеалдаркинском говоре чувашского языка не бытует.

Подобная ситуация также фиксируется для различных названий реки, протекаю- 
щей через село Ново-Геранькино, чувашское население которого является родственным чувашам Большого Алдаркино. В Ново-Геранькино река, официально именующаяся Чувайка (приток Кутулука) местным чувашским населением называется так же, как и в Большом Алдаркино, - Сирма. Информанты в Ново-Геранькино объясняли нам происхождение указанных названий следующим образом: «У нас одна тут река, поэтому просто называем - Сирма. Чувайкой это уже русские назвали. Почему? Ну так население здесь у нас - чуваши, потому и Чувайка» [ПМА 2018: инф. 2].

Лексема сирма в большинстве чувашских говоров Борского и смежных с ним районов Самарской области имеет значение 'река', параллельно бытующее значение 'овраг' для неё зафиксировано нами лишь в новогеранькинском говоре. Однако и в данном говоре сирма, прежде всего, используется в значении 'река' в разговорной речи, при этом в топонимии употребляется исключительно в значении 'река'. В составе названий оврагов в новогеранькинском говоре употребляется русский термин дол.

Надо отметить, что в большеалдаркинском говоре в данном значении используется термин вар, который у аверкинских чувашей уже считается архаизмом, а в значении 'овраг' в аверкинском говоре употребляется термин лобашка [ПМА 2019: инф. 3; ПМА 2019: инф. 4].

Скобелевский пруд. Название одного из прудов, расположенных на территории Бузулукского бора в окрестностях Большого Алдаркино. По словам информантов, большинство названий объектов и урочищ на территории бора восходят к фамилиям местных лесников, о происхождении же данного конкретного названия им ничего не известно. В памяти местных жителей сохраняется несколько фамилий местных лесников, в зону ответственности которых входили окрестности Большого Алдаркино: в 1925-1929 гг. здесь был лесник по фамилии Колесников, после него - Барабанов. По нашему мнению, в данном случае название пруда восходит к фамилии барина одного из окрестных сёл, - так, в окрестностях бора имеется урочище Скобелево. Это село возникло в первой половине XIX в., его другое название - Богоявленское, по престолу местной церкви. Оно было основано на зем- лях, пожалованных генералу-лейтенанту Ивану Никитичу Скобелеву (1778-1849 гг.), являвшемуся дедом известного русского полководца, героя русско-турецкой войны 1877-1878 гг. М. Д. Скобелева. Видимо, данный пруд был сооружён по инициативе одного из помещиков этого села.

Тихон вар. Название одного из отвершков оврага Тури вар. Назван так по имени проживавшего некогда рядом с ним местного жителя Тихона Иванова. Термин вар, как мы уже указывали, употребляется в большеалдаркинском говоре чувашского языка в значении 'овраг'.

Тихон ошкень. Одно из устаревших названий улиц в Большом Алдаркино. Ранее эта улица начиналась за оврагом Тихон вар. Что первично - название улицы или оврага - в настоящее время неизвестно.

Тури. Название района села, расположенного на северной, возвышенной стороне. По сведениям Д. И. Ерицева, здесь раньше была улица, в 1950-х гг., после войны она исчезла, а название сохранилось [ЛА 2018: 2]. Такие названия часто встречаются в топонимии чувашских селений применительно к тем их частям, которые расположены на относительном возвышении, либо выше по течению местной реки.

Тури вар. Самый протяжённый овраг в Большом Алдаркино, в который впадают несколько малых оврагов, также имеющих свои названия. Данный топоним восходит к чувашским лексемам тури 'верхний' и вар 'овраг'. Интересен спектр значений, приведённый для географического термина вар Н. И. Ашмариным в различных чувашских говорах, среди них: 'обдернелый овраг с пологими краями', 'лог', ‘дол', 'глубокий и длинный овраг с крутыми обрывистыми берегами и сухой', 'глубокое сухое русло ручья', 'безводная ложбина'; на материале ряда говоров учёный отмечает различие терминов вар и с̧ырма: вар - 'овраг в лесу', с̧ырма - 'овраг в поле'; вар - 'сухое начало с̧ырма (без воды)’ [Ашмарин 1930, V: 167].

Чук вар. Название одного из отвершков оврага Тури вар. Согласно сведениям Д. И. Ерицева, овраг получил своё название вследствие того, что здесь «староверы» совершали свои религиозные обряды [ЛА 2018: 3]. Под «староверами», видимо, следует понимать последователей чувашской 
традиционной религии, а не старообрядцев, общин которых в Большом Алдаркино исторически не фиксируется. Названия мест языческих жертвоприношений в традиционной религии чувашей часто включают в себя элемент чу”к со значением 'жертва', который в ряде исследований отмечается как устаревшая лексема [Егоров 1964: 328].

В разговорной речи чувашей Заволжья, действительно, эта лексема фиксируется редко, в большинстве говоров её значение утрачено. В топонимии ряда чувашских сёл Самарского Заволжья данный термин вытеснил лексему киреметь в названиях мест традиционных молений [Беленов 2018]. Как мы уже отмечали выше, изначальное разделение в чувашской традиционной религии мест молений киреметь и чйк в большинстве чувашских сёл Заволжья в настоящее время забыто.

Ялдра. Название одной из частей села Большое Алдаркино. По мнению Д. И. Ерицева, основа ял в данном названии явно указывает на то, что первые поселенцы села обосновались именно на этом месте [ЛА 2018: 3]. Дополнительным аргументом в пользу данного предположения является тот факт, что в данном районе до настоящего времени проживают потомки Алдаровых, Андреевых и Максимовых носители старейших фамилий Большого Алдаркино. Возможно, топоним восходит к словосочетанию ял + тӑра (вариация лексемы тавра в ряде говоров верхового диалекта, например, в сундырском) 'окрестность села', где ял- 'село', 'деревня’; тӑра - 'окрестность', 'окружающая местность'. Кроме того, известны чувашские ойконимы Ялтӑра в бывшем Ядринском уезде [Ашмарин 1929, IV: 330-333], Уйnус̧ Ялтацра в Шумерлинском районе и ряд других. На территории Чувашии топонимические предания, бытующие в соответствующих сёлах, возводят данные ойконимы к имени основателя сёл - Ялдра.

\section{Полевой материал автора}

ПМА 2018: инф. 1 - Валентина Петровна Дробышева, 1961 г. р. Запись в с. Большое Алдаркино (Борский район, Самарская область), 2018 г.

ПМА 2018: инф. 2 - Петрова Нина Семёновна, 1950 г. р. Запись в с. Ново-Геранькино (Бор-

\section{Заключение}

В топонимии села Большое Алдаркино и его окрестностей нашли отражение специфические черты верхового диалекта чувашского языка, к которому относится большеалдаркинский говор. В частности, они прослеживаются в таких названиях, как: Odap, Вырас ошкень, Тихон ошкень, Ялдра.

Географические названия большеалдаркинского топонимического пространства этимологизируются на основе чувашского и русского языков. Субстратный слой в данном топонимическом пространстве нами не выявлен, вследствие чего можно предполагать, что пришедшие на территорию Бузулукского бора в XVIII в. чуваши либо не застали здесь предыдущих насельников, либо языковые контакты с ними были недостаточны для передачи географической номенклатуры. При этом характерно, что названия, сформировавшиеся в поздний период истории села (примерно с середины XX в.) изобилуют русизмами, которые практически отсутствуют (если исключить отантропонимные названия и географические названия, относящиеся к объектам, занимающим пограничное положение с топонимическими пространствами русских сёл) в топонимах, возникших на более ранних этапах истории Большого Алдаркино.

Часть чувашских географических названий в настоящее время деэтимологизирована, и их значение для современных носителей большеалдаркинского говора неясно, при этом чувашское происхождение данных названий ими под сомнение не ставится.

Интересно отметить высокую топогенетичность географического термина вар в значении 'овраг' в исследуемом топонимическом пространстве, особенно на контрасте с топонимическими пространствами аверкинских чувашей, а также с топонимическим пространством села Ново-Геранькино, говоры которых относятся к тому же, верховому диалекту чувашского языка.

ский район, Самарская область), 2018 г.

ПМА 2019: инф. 3 - Раиса Николаевна Андреева, 1954 г. р. Запись в с. Ахрат (Похвистневский район, Самарская область), 2019 г.

ПМА 2019: инф. 4 - Мария Степанова, 1996 г. p. Запись в с. Среднее Аверкино (Похвистневский район, Самарская область), 2019 г. 


\section{Author's Field Data}

Informant: Mariya Stepanova, b. 1996. Rec. in Srednee Averkino (Pokhvistnevsky District, Samara Oblast) in 2019. (In Russ.)

Informant: Nina S. Petrova, b. 1950. Rec. in NovoGerankino (Borsky District, Samara Oblast) in 2018. (In Russ.)

\section{Источники}

ЛА 2018 - Личный архив Д. И. Ерицева. Большое Алдаркино, 2018 г.

Рукопись 1998 - Рукопись П. Д. Лупаева (Загвоздкина) «Записки о прошлом» // Сергиевский историко-краеведческий музей (с. Сергиевск, Самарская обл.). Фонд рукописей. Д. 128.

\section{Литература}

Ашмарин 1902 - Ашмарин Н. И. Болгары и чуваши. Казань: Типо-лит. Имп. ун-та, 1902. $133 \mathrm{c}$.

Ашмарин 1921 - Аимарин Н. И. Отголоски золотоордынской старины в народных верованиях чуваш // Известия Северо-восточного археологического и этнографического института в Казани. 1921. Т. 2. С. 93-128

Ашмарин 1928-1950-Ашмарин Н. И. Словарь чувашского языка в 17 томах. Казань; Чебоксары: Изд. Наркомата по просвещ. ЧАССР, 1928-1950: T. 1. 1928; Т. 2. 1929; Т. 3. 1929; T. 4. 1929; T. 5. 1930; T. 6. 1934; T. 7. 1934; T. 8. 1935; T. 9. 1935; T. 10. 1936; T. 11. 1936; T. 12. 1937 ; T. 13. 1937 ; T. 14. 1937 ; T. 15 1938; Т. 16. 1941; Т. 17. 1950.

Барашков, Дубман, Смирнов 1996 - Барашков В. Ф., Дубман Э. Л., Смирнов Ю. Н. Самарская топонимика. Самара: СамГУ, 1996. $192 \mathrm{c}$.

Беленов 2018 - Беленов Н. В. Эволюция названий культовых мест у чувашей левобережья Самарского Поволжья // Языковые единицы в свете современных научных парадигм. Уфа: Башкирский гос. ун-т, 2018. С. 291295.

Бурыкин 2014 - Бурыкин А. А. Имена собственные как исторический источник: по материалам русских документов об открытии и освоении Сибири и Дальнего Востока России XVII-XIX веков. СПб.: Петербургское востоковедение, 2014. 532 с.

Димитриев 1993 - Димитриев В. Д. Чувашские исторические предания. Чебоксары: Чувашское кн. изд-во, 1993. 446 с.

Дыбо 2013 - Дыбо А. В. Сюнну-Гунны. Кто же они? Стенограмма публичной лекции от
Informant: Raisa N. Andreeva, b. 1954. Rec. in Akhrat (Pokhvistnevsky District, Samara Oblast) in 2019. (In Russ.)

Informant: Valentina P. Drobysheva, b. 1961. Rec. in Bolshoe Aldarkino (Borsky District, Samara Oblast) in 2018. (In Russ.)

\section{Sources}

Lupaev (Zagvozdkin) P. D. Notes on the Past. Manuscript. At: Sergievsk Museum of Local History and Lore (Sergievsk, Samara Oblast), Manuscript Collection. D. 128. (In Russ.)

Personal archives of D. I. Eritsev. Bolshoe Aldarkino, 2018. (In Russ.)

24 октября 2013 г. [электронный ресурс] // Полит.ру. Лекции. 1.12.2013. URL: https:// polit.ru/article/2013/12/01/dibo/ (дата обращения: 10.02.2021).

Егоров 1964 - Егоров В. Г. Этимологический словарь чувашского языка. Чебоксары: Чувашск. кн. изд-во, 1964. 356 с.

Иванова 2005 - Иванова А. С. Типология чувашских гидронимов: дисс. ... канд. фил. наук. Чебоксары, 2005. 359 с.

Исаев 2018 - Исаев Ю. Н. Поволжский топоним «Шигали» (этимолого-фольклорные сюжеты) // Развитие образования. 2018. № 1. C. 5-8.

Исаев, Исаев 2018 - Исаев Ю. Н., Исаев Л. Ю. Чебоксары: топонимические этюды // Развитие образования. 2018. № 2. С. 7-12

Канюкова 1965 - Канюкова $A$. С. Чувашская диалектология. Чебоксары: Чувашск. кн. изд-во, 1965. $147 \mathrm{c.}$

Карта 1867 - Карта Самарской губернии, составленная в 1867 г. членами Самарского губернского статистического комитета: П. А. Рихтером и И. Ф. Станевичем [электронный ресурс] // Самара: Изд. Самарского губ. стат. ком-та; Картографическое заведение А. Ильина, 1867. URL: http://www. etomesto.ru/map-samara_1867-guberniya/ (дата обращения: 10.02.2021).

Комиссаров 1911 - Комиссаров Г. И. Чуваши Казанского Заволжья // Известия общества археологии, истории и этнографии при Императорском Казанском университете. T. XXVII, вып. 5. Казань: Типо-лит. Имп. ун-та, 1911. С. 311-432.

Корнилов 2005 - Корнилов Г. Е. Топонимия республик Поволжья (Башкортостан, Коми, 
Марий Эл, Мордовия, Татарстан, Удмуртия, Чувашия) // Вестник Чувашского университета. 2005. № 1. С. 140-192

Магницкий 1905 - Магниикий В. К. Чувашские языческие имена. Казань: Тип. Казанского ун-та, 1905. $101 \mathrm{c}$.

Мадиева, Супрун 2015 - Мадиева Г. Б., Супрун В. И. Теория и практика ономастики. Астана; Волгоград: Перемена, 2015. 199 с.

Матвеев 2006 - Матвеев A. К. Ономатология. М.: Наука, 2006. 290 с.

Насилов, Бурыкин 2017 - Насилов Д. М., Бурыкин A. A. «Корневой чувашско-русский словарь» Н. И. Золотницкого как источник по ономастике Поволжья // Ономастика Поволжья. 2017. С. 145-151.

Нестеров 2017 - Нестеров B. А. Над картой Чувашии: историко-топонимические заметки. Чебоксары: Чувашск. кн. изда-во, 2017. $142 \mathrm{c}$

Никольский 1911 - Никольский Н. В. Краткий конспект по этнографии чуваш. Казань: Типо-лит. Имп. ун-та, 1911. 114 с.

Никонов 1965 - Никонов В. А. Введение в топонимику. М.: Наука, 1965. 179 с.

\section{References}

Ashmarin N. I. Bulgarians and Chuvashes. Kazan: Imperial Kazan University, 1902. 133 p. (In Russ.)

Ashmarin N. I. Dictionary of the Chuvash Language. In 17 vols. Kazan; Cheboksary: People's Commissariat for Education (Chuvash ASSR), 1928-1950. (In Chuv. and Russ.)

Ashmarin N. I. Vestiges of the Golden Horde era in Chuvash folk beliefs. Izvestiya Severo-vostochnogo arkheologicheskogo i etnograficheskogo instituta v Kazani. 1921. Vol. 2. Pp. 93-128. (In Russ.)

Barashkov V. F., Dubman E. L., Smirnov Yu. N. Toponymy of Samara Oblast. Samara: Samara State University, 1996. 192 p. (In Russ.)

Belenov N. V. Chuvash places of worship in the left-bank Samara Volga region: evolution of the toponyms revisited. In: Language Units in Light of Modern Scientific Paradigms. Ufa: Bashkir State University, 2018. Pp. 291-295. (In Russ.)

Burykin A. A. Personal Names as a Historical Source: Analyzing Russian Documents from the Era of Russia's Conquest of Siberia and the Far East, $17^{\text {th }}-19^{\text {th }}$ Centuries. St. Petersburg: Peterburgskoe Vostokovedenie, 2014. 532 p. (In Russ.)
Сергеев 2007 - Сергеев Л. П. Диалектная система чувашского языка. Чебоксары: ЧГПУ, 2007. $428 \mathrm{c}$.

Серебренников 1959 - Серебренников Б. А. О методах изучения топонимических названий // Вопросы языкознания. 1959. № 6. С. $36-50$.

Симаков 2008 - Симаков В. Е. Энциклопедия чувашских сёл Самарской области. Самара: НТЦ, 2008. 404 c.

Сосаева 1997 - Сосаева A. А. Хронологические пласты топонимов Чувашии // Материалы по чувашской диалектологии. Чебоксары: ЧГИГН, 1997. С. 62-65.

Федотов 1996 - Федотов М. Р. Этимологический словарь чувашского языка в 2 томах. Чебоксары: ЧГИГН, 1996. $470+509$ с.

Цыганкин 2005 - Цыганкин Д. В. Память, запечатлённая в слове. Саранск: Красный октябрь, 2005. $432 \mathrm{c.}$

Юмарт 2003 - Юмарт Г. Ф. Фольклорные и литературные штрихи // Чуваши Самарской Луки. Чебоксары: ЧГИГН, 2003. С. 135-149.

Ягафова 1998 - Ягафова Е. А. Самарские чуваши. Самара: ИЭКА Поволжье, 1998. 368 с.

Dimitriev V. D. Chuvash Historical Tales. Cheboksary: Chuvash Book Publ., 1993. 446 p. (In Russ.)

Dybo A. V. Xiongnu-Huns: Who Were/Are They? Verbatim report of a public lecture delivered on October 24, 2013. On: Polit.ru. Lectures. Posted on December 1, 2013. Available at: https:// polit.ru/article/2013/12/01/dibo/ (accessed: February 10, 2021). (In Russ.)

Egorov V. G. Etymological Dictionary of the Chuvash Language. Cheboksary: Chuvash Book Publ., 1964. 356 p. (In Chuv. and Russ.)

Fedotov M. R. Etymological Dictionary of the Chuvash Language. In 2 vols. Cheboksary: Chuvash State Institute for the Humanities, 1996. $470+509$ p. (In Chuv. and Russ.)

Isaev Yu. N. Volga toponym 'Shigali' (etymological and folklore subjects). Development of Education. 2018. No. 1. Pp. 5-8. (In Russ.)

Isaev Yu. N., Isaev L. Yu. Cheboksary: toponymic sketches. Development of Education. 2018. No.2. Pp. 7-12. (In Russ.)

Ivanova A. S. Typology of Chuvash Hydronyms. Cand. Sc. (philology) thesis. Cheboksary, 2005. 359 p. (In Russ.)

Kanyukova A. S. Chuvash Dialectology. Cheboksary: Chuvash Book Publ., 1965. 147 p. (In Russ.) 
Komissarov G. I. Chuvashes of the left-bank Kazan Volga region. Izvestiya obshchestva arkheologii, istorii i etnografii pri Imperatorskom Kazanskom universitete. 1911. Vol. XXVII. No. 5. Pp. 311-432. (In Russ.)

Kornilov G. E. Toponymy of the Volga republics: Bashkortostan, Komi, Mari El, Mordovia, Tatarstan, Udmurtia, Chuvashia. Vestnik Chuvashskogo universiteta. 2005. No. 1. Pp. 140192. (In Russ.)

Madieva G. B., Suprun V. I. Theory and Practice of Onomastics. Astana; Volgograd: Peremena, 2015. 199 p. (In Russ.)

Magnitsky V. K. Chuvash Pagan Names. Kazan: Imperial Kazan University, 1905. 101 p. (In Russ.)

Map of Samara Governorate Compiled in 1867 by Members of Samara Governorate's Statistical Committee P. A. Richter and I. F. Stanevich. Samara: Samara Governorate's Statistical Committee; A. Ilyin, 1867. On: EtoMesto.ru (online database of old maps). Available at: http:// www.etomesto.ru/map-samara_1867-guberniya/ (accessed: February 10, 2021). (In Russ.)

Matveev A. K. Onomatology. Moscow: Nauka, 2006. 290 p. (In Eng.)

Nasilov D. M., Burykin A. A. Chuvash-Russian Word-Stem Dictionary by N. I. Zolotnitsky as a source on onomastics of the Volga Region. In: Onomastics of the Volga Region. 2017. Pp. 145-151. (In Russ.)
Nesterov V. A. Over Chuvashia's Map: Historical and Toponymic Notes. Cheboksary: Chuvash Book Publ., 2017. 142 p. (In Russ.)

Nikolsky N. V. Chuvash Ethnography: A Brief Work-Book. Kazan: Imperial Kazan University, 1911. 114 p. (In Russ.)

Nikonov V. A. An Introduction to Toponymy. Moscow: Nauka, 1965. 179 p. (In Russ.)

Serebrennikov B. A. Toponymic names: research methods revisited. Voprosy Jazykoznanija. 1959. No. 6. Pp. 36-50. (In Russ.)

Sergeev L. P. Chuvash Dialect System. Cheboksary: Chuvash State Pedagogical University, 2007. 428 p. (In Russ.)

Simakov V. E. Chuvash Villages of Samara Oblast: Encyclopedia. Samara: NTTs, 2008. 404 p. (In Russ.)

Sosaeva A. A. Chronological strata of Chuvashia's toponymy. In: Materials in Chuvash Dialectology. Cheboksary: Chuvash State Institute for the Humanities, 1997. Pp. 62-65. (In Russ.)

Tsygankin D. V. Memory Manifested in Word. Saransk: Krasnyi Oktyabr, 2005. 432 p. (In Russ.)

Yagafova E. A. Samara Chuvashes. Samara: Povolzhye, 1998. 368 p. (In Russ.)

Yumart G. F. Folklore and literary notes. In: Chuvashes of Samara Luka. Cheboksary: Chuvash State Institute for the Humanities, 2003. Pp. 135-149. (In Russ.) 